\title{
Serum creatine kinase studies in the detection of carriers of Duchenne dystrophy
}

\author{
R. C. HUGHES, DOROTHY C. PARK, MARY E. PARSONS, AND \\ M. D. O'BRIFN \\ From the Regional Neurological Centre, The General Hospital, Newcastle upon Tyne
}

SUMMARY A number of methods which might improve the detection of carriers of Duchenne muscular dystrophy, based on the estimation of serum creatine kinase (CK), have been tried in an attempt to improve the $70 \%$ detection rate obtained with random samples. One series of experiments involved controlled exercise on a bicycle ergometer, the second series was based on sampling of muscle venous blood after controlled ischaemic exercise, and a third series of experiments was carried out to see whether the rate of enzyme inactivation was different in carriers of Duchenne dystrophy compared with controls. These methods were not found to improve the carrier detection rate based upon serum $\mathrm{CK}$ estimation.

Reliable carrier detection is the basis of genetic counselling for those women who may carry the gene responsible for $\mathrm{x}$-linked muscular dystrophy of the Duchenne type. Studies of known carriers, determined by having an affected male relative and an affected male child, have shown that about $70 \%$ have a raised mixed venous creatine kinase (CK). This is presumed to be due to a leakage of the enzyme from the muscle fibres involved by the dystrophic process; this leakage may be increased by exercise (Emery, 1967). It has been observed that the serum CK of normal women tends to rise during the day (Thomson, 1968). A diurnal rise in serum CK was reported by Stephens and Lewin (1965) to occur in carriers but not in normals. It is likely that this diurnal variation is due to muscular activity during the day; though no consistent rise in serum CK was found after moderate exercise in either normals or known carriers by Hudgson, Gardner-Medwin, Pennington, and Walton (1967). The problem remains that 25 to $30 \%$ of known carriers for the gene for Duchenne dystrophy can not be detected by serum CK estimations, either resting or after exercise (Hudgson et al., 1967; Emery, 1969). Studies of other parameters including muscle histology (Pearce et al., 1966; Emery, 1965), quantitative electromyography (Gardner-Medwin, 1968), muscle lactate dehydrogenase isoenzymes (Johnston, Wilkinson, Withycombe, and Raymond, 1966), and total body potassium (Blahd, Cassen, and Lederer, 1964; Blahd, Lederer, and Cassen, 1967) have done little to increase this detec- tion rate. Roy and Dubowitz (1970) have recently reported two cases with normal serum CK levels who showed ultrastructural abnormalities in their muscle biopsies.

There are a number of possible explanations for the normal CK values found in some definite carriers. It may be that there are two populations of carriers, one normal and one abnormal in respect of $\mathbf{C K}$ production or inactivation. If this is the case then no elaboration of a test based on CK values would improve the detection rate. However, it is more likely that carriers with normal resting CK levels form the lower end of a continuous spectrum; it might therefore be possible to improve the detection rate with the use of a controlled testing procedure. In this study two possibilities have been tested experimentally. First we studied the effect of standard exercise; this was strenuous, but not sufficient to produce an excessive rise of the serum CK in normal subjects. Secondly, samples of blood were taken directly from muscle venous effluent, after ischaemic exercise, thus avoiding dilution with blood from other sources; ischaemic exercise was used because it has been shown that ischaemia will provoke a rise in the serum CK in dystrophic patients but not in normal subjects (Lanari, Gonzalez Perez, and Semeniuk, 1970).

It is possible that those carriers who have normal levels of serum CK have an increased ability to clear (inactivate or metabolize) $\mathrm{CK}$ and perhaps also other enzymes. This is difficult to investigate 
because very little is known about the clearance of enzymes from serum. However, two possibilities have been investigated: a muscle $\mathrm{CK}$ preparation has been incubated with serum to determine whether or not serum from carriers inactivates this enzyme more rapidly than normal, and serum levels of an enzyme not derived from muscle (alkaline phosphatase) have been measured to see if carriers have values lower than normal.

Serum CK activity was measured by the method described by Pearce, Pennington, and Walton (1964). The upper limit of normal for adult women is taken as 75 i.u./1.

\section{STRENUOUS EXERCISE ON A BICYCLE ERGOMETER}

\section{PATIENTS AND METHOD}

Five definite carriers, six possible carriers and three control subjects undertook 10 to 15 minutes of strenuous exercise on a bicycle ergometer. The amount of work done in each group, measured in kilopond metres (KPM), is shown in Table 1. One KPM is the work done by raising a mass of $1 \mathrm{~kg}$ through 1 metre and is equivalent to $7 \cdot 23$ foot pounds. The exercise was performed without previous training and samples of venous blood for CK estimation were taken before the exercise and at intervals after exercise as shown in Table 1.

\section{RESULTS AND DISCUSSION}

The results are given in Table 1. Previous observations in normal subjects (Vejjajiva and Teasdale,,$\widehat{0}$ 1965; Griffiths, 1966) which show that strenuous exercise can cause a rise in CK have been confirmed, but no CK value obtained in this series exceeded the upper limit of normal (75 i.u./1), only one definite carrier (patient no. 2) showed a progressive: rise in CK over the 24 hour period after exercises and only one possible carrier (patient no. 8) showedo a rise immediately after exercise. The average valueso showed a tendency to fall with time despite the factos that both patients and controls continued to bed mobile. It is of interest that the average value on the morning after the exercise was usually lower than ${ }^{\text {s }}$ the pre-exercise value, suggesting that normalo activity before the test was sufficient to produce a slight rise in CK level.

\section{SAMPLING OF MUSCLE VENOUS EFFLUENT}

\section{PATIENTS AND METHOD}

Two known carriers were studied, both of whom wetr known to have raised resting CK values. These patientso attended the hospital as outpatients and had therefore? taken some exercise before the test. A pre-test mixed

TABLE 1

SERUM CREATINE KINASE ACTIVITY (I.U./L.) BEFORE AND AFTER EXERCISE

\begin{tabular}{|c|c|c|c|c|c|c|c|c|}
\hline \multirow[t]{2}{*}{ Subjects } & \multirow{2}{*}{$\begin{array}{l}\text { Age } \\
(y r .)\end{array}$} & \multirow{2}{*}{$\begin{array}{l}\text { Previous } \\
\text { random } \\
\text { samples }\end{array}$} & \multirow{2}{*}{$\begin{array}{l}\text { Pre-exercise } \\
\text { CK activity }\end{array}$} & \multicolumn{4}{|c|}{ Post-exercise CK activity } & \multirow{2}{*}{$\begin{array}{l}\text { Work done } \\
(K P M)\end{array}$} \\
\hline & & & & $\frac{1}{2} h r$. & $2 \mathrm{hr}$. & $4 h r$. & $20 \mathrm{hr}$. & \\
\hline \multicolumn{9}{|l|}{ Definite carriers } \\
\hline $\begin{array}{l}1 \\
2\end{array}$ & 22 & $25 \cdot 6$ & $\begin{array}{l}29 \cdot 5 \\
41 \cdot 0\end{array}$ & 33.7 & 33.5 & 32.5 & $27 \cdot 3$ & 3125 \\
\hline 3 & $\begin{array}{l}62 \\
39\end{array}$ & $\begin{array}{l}42 \cdot 8 \\
60 \cdot 1\end{array}$ & $\begin{array}{l}\begin{array}{l}41 \cdot 0 \\
61 \cdot 1\end{array} \\
-\end{array}$ & $\begin{array}{l}44 \cdot 5 \\
5 \cdot 1\end{array}$ & $\begin{array}{l}50 \cdot 7 \\
46 \cdot 3\end{array}$ & $\begin{array}{l}54 \cdot 0 \\
44 \cdot 0\end{array}$ & $\begin{array}{l}58 \cdot 0 \\
40.1\end{array}$ & $\begin{array}{l}3400 \\
3100\end{array}$ \\
\hline 4 & 26 & $34 \cdot 2$ & 37.7 & $\begin{array}{l}53 \cdot 1 \\
36 \cdot 7\end{array}$ & $\begin{array}{l}46 \cdot 3 \\
34 \cdot 0\end{array}$ & $\begin{array}{l}44.0 \\
36.7\end{array}$ & $26 \cdot 2$ & $\begin{array}{l}3100 \\
4850\end{array}$ \\
\hline \multirow[t]{2}{*}{5} & 40 & $54 \cdot 7$ & $49 \cdot 7$ & $44 \cdot 0$ & $48 \cdot 3$ & $40 \cdot 0$ & $33 \cdot 0$ & 4600 \\
\hline & 39 & $43 \cdot 5$ & $43 \cdot 8$ & $42 \cdot 4$ & $42 \cdot 4$ & $41 \cdot 4$ & 36.9 & 3815 \\
\hline \multicolumn{9}{|l|}{ Possible carriers } \\
\hline 6 & 22 & & $26 \cdot 0$ & $24 \cdot 5$ & 22.7 & $22 \cdot 0$ & & 4000 \\
\hline 7 & 26 & $32 \cdot 5$ & $20 \cdot 0$ & $20 \cdot 0$ & $19 \cdot 3$ & $18 \cdot 8$ & 14.9 & 3650 \\
\hline 8 & 29 & & $27 \cdot 7$ & $41 \cdot 2$ & $41 \cdot 5$ & $35 \cdot 8$ & $33 \cdot 2$ & 5350 \\
\hline 9 & 20 & 25.6 & $28 \cdot 0$ & $26 \cdot 1$ & $30 \cdot 6$ & $30 \cdot 5$ & $22 \cdot 6$ & 4100 \\
\hline 10 & 25 & $23 \cdot 0$ & $19 \cdot 8$ & 24.9 & $22 \cdot 0$ & $39 \cdot 6$ & $17 \cdot 3$ & 5550 \\
\hline \multirow[t]{2}{*}{11} & 15 & & $37 \cdot 7$ & $44 \cdot 7$ & $44 \cdot 7$ & $43 \cdot 5$ & $39 \cdot 2$ & 5700 \\
\hline & 23 & & $26 \cdot 5$ & $30 \cdot 2$ & $30 \cdot 1$ & $31 \cdot 7$ & $25 \cdot 5$ & 4725 \\
\hline \multicolumn{9}{|l|}{ Controls } \\
\hline 12 & 22 & & 22.5 & $25 \cdot 0$ & & $30 \cdot 0$ & & 7700 \\
\hline \multirow{3}{*}{14} & 19 & & $26 \cdot 0$ & $27 \cdot 5$ & & $26 \cdot 3$ & & 5300 \\
\hline & 22 & & $29 \cdot 5$ & $29 \cdot 5$ & & $26 \cdot 4$ & & 5000 \\
\hline & 21 & & $26 \cdot 0$ & $27 \cdot 3$ & & $27 \cdot 6$ & & 6000 \\
\hline
\end{tabular}


venous sample was taken for CK estimation and an intravenous catheter was then placed in a vein draining the deep muscle compartment on the flexor aspect of the forearm. A sample from the catheter was taken with a cuff placed at the wrist and inflated to above systolic pressure to exclude the contribution of blood from the hand. Two minutes of ischaemic exercise then followed with a second cuff on the upper arm inflated to above systolic pressure. The exercise was graded to the maximum available power of the flexor muscles and the patient was asked to exert $50 \%$ of the maximal grip every two seconds for two minutes. Immediately after exercise samples from the catheter were taken and further samples were taken at half-hourly intervals thereafter for six hours; before each sample was taken the wrist and upper arm cuffs were inflated for one minute. At the end of the experiment a second mixed venous sample was taken.

\section{RESULTS AND DISCUSSION}

The results are shown in Table 2. There is no significant difference in serum CK activity between the initial mixed venous sample and the sample of blood obtained from the catheter either before or after a period of ischaemic exercise. It is apparent that sampling from muscle venous effluent does not give higher values for serum CK than in samples taken from mixed venous blood. We have not therefore been able to confirm other reports (Weisman, Moser, Richerich, and Rossi, 1965) in which a rise of CK activity was found four minutes after 45 seconds of ischaemic exercise when sampling from a superficial vein in four carriers of Duchenne dystrophy. It seems possible that this failure to produce a further rise in CK levels in carriers, who are known to have abnormally high values, is due to the small mass of muscle exercised and to the short duration of the ischaemic exercise, or it may be that the enzyme is released over a prolonged period and therefore diluted in the general circulation.

\section{CLEARANCE OF SERUM ENZYMES BY CARRIERS}

a. CREATINE KINASE INACTIVATION Sera from three normal women, four definite carriers, and two possible carriers were incubated at $37^{\circ} \mathrm{C}$ for 30 minutes with rabbit muscle CK (The Boehringer Corp. Ltd.). A stock solution of CK was prepared by dissolving $10 \mathrm{mg}$ lyophilized CK in $1.0 \mathrm{ml}$. water and then diluting to $10 \mathrm{ml}$. with $5 \%$ bovine serum albumin. The same stock solution was used throughout and kept frozen in between experiments. For use it was diluted $1 / 2,500$ or $1 / 5,000$ with $0.9 \% \mathrm{NaCl}$. In most experiments equal volumes of serum and diluted CK were mixed but in two later experiments on carriers 9 vol. serum were mixed with 1 vol. 1/5000 CK. In each experiment the mixture of serum and diluted $\mathrm{CK}$ was put into two tubes: one tube was kept in a beaker of ice and the other was incubated for 30 minutes at $37^{\circ} \mathrm{C}$. Then CK activity in each was assayed. The amount of inactivation after incubation with normal serum was very small $-6 \%$, nil, and $17 \%$. The amount of inactivation after incubation with serum from definite carriers was no greater $-7 \%, 5 \%$, nil, $2 \%$. It was concluded that under the experimental conditions described there was no difference between normal and carrier sera with respect to $\mathrm{CK}$ inactivation.

b. SERUM ALKALINE PHOSPHATASE LEVELS IN CARRIERS WITH NORMAL CK LEVELS If those carriers with normal serum CK levels do have an increased ability to clear creatine kinase it is conceivable that they might have serum activities of other (non-muscle) enzymes which lie below or in the lower part of the normal range. Accordingly serum alkaline phosphatase (Alk. P-ase) activities were estimated in four definite carriers, one possible carrier, and three controls. Alkaline phosphatase was assayed by the method of Bessey, Lowry, and Brock (1946); normal range $1 \cdot 0-2 \cdot 5 \mathrm{~m} . \mathrm{mole} / \mathrm{hr} / 1$. The results are shown in Table 3.

The serum alkaline phosphatase activities of the definite carriers and the possible carriers were within the normal range except for one (patient no. 4) who had a level just below normal. Although the numbers are too small to allow statistical analysis it was concluded that there was no indication that the serum alkaline phosphatase is abnormally low in carriers with normal serum CK levels and this study was not pursued further.

\section{CONCLUSION}

A number of methods which might improve the detection of carriers of Duchenne dystrophy have been tried without success. It seems possible that

\section{TABLE 2}

COMPARISON BETWEEN SERUM CK ACTIVITY (I.U./L.) IN MIXED VENOUS BLOOD AND VENOUS EFFLUENT FROM MUSCLE IN TWO KNOWN CARRIERS

\begin{tabular}{|c|c|c|c|c|c|c|c|c|c|c|c|c|c|c|}
\hline \multirow{2}{*}{$\begin{array}{l}\text { Pt. } \\
\text { no. }\end{array}$} & \multirow{2}{*}{$\begin{array}{l}\text { Mixed } \\
\text { venous }\end{array}$} & \multirow{2}{*}{$\begin{array}{c}\text { Pre- } \\
\text { exercise } \\
\text { (muscle } \\
\text { effluent) }\end{array}$} & \multicolumn{11}{|c|}{ Post-exercise (min.) (muscle effluent) } & \multirow{2}{*}{$\begin{array}{c}\text { Mixed } \\
\text { venous } \\
300 \text { min }\end{array}$} \\
\hline & & & 0 & 30 & 60 & 90 & 120 & 150 & 180 & 210 & 240 & 270 & 300 & \\
\hline 15 & 159 & 168 & 172 & 158 & 170 & 168 & 166 & 163 & 167 & 159 & 172 & 165 & 173 & 144 \\
\hline 16 & 675 & 692 & 653 & 667 & 621 & 598 & 555 & 625 & 573 & 570 & 642 & 541 & 583 & 547 \\
\hline
\end{tabular}


TABLE 3

SERUM ALKALINE PHOSPHATASE ACTIVITIES (M-MOLE/HR./L.)

\begin{tabular}{lccc}
\hline \multicolumn{1}{c}{ Subjects } & $\begin{array}{c}\text { Age } \\
(\text { yr. })\end{array}$ & $\begin{array}{c}\text { Serum } \text { CK } \\
(\text { i.u. } / 1 .)\end{array}$ & $\begin{array}{c}\text { Serum alkaline } P \text {-ase } \\
(\text { m-mole/hr./1. })\end{array}$ \\
\hline Definite carriers & & & \\
$\quad 1$ & 22 & 33 & $1 \cdot 6$ \\
2 & 62 & 47 & $2 \cdot 4$ \\
3 & 39 & 65 & $1 \cdot 2$ \\
4 & 26 & 26 & $0 \cdot 8$ \\
Possible carrier & & & \\
6 & 22 & 26 & $1 \cdot 3$ \\
Controls & & & \\
11 & 22 & 19 & $1 \cdot 4$ \\
12 & 19 & 25 & $1 \cdot 4$ \\
13 & 22 & 48 & $1 \cdot 3$ \\
\hline
\end{tabular}

Numbers refer to same subjects as in Table 1.

those known carriers who are not detectable by the presence of a raised serum CK activity do not have sufficient muscle fibres affected or else the severity of the dystrophic process is not sufficient to increase the level of circulating CK under the test conditions described.

We are grateful to Professor J. N. Walton and Dr. R. J. T. Pennington for their help and encouragement, to Mrs. Hazel Potts for carrying out the serum creatine kinase analyses, and to subjects and normal volunteers for their cooperation.

\section{REFERENCES}

Bessey, O. A., Lowry, O. H., and Brock, M. J. (1946). A method for the rapid determination of alkaline phosphatase with five cubic millimeters of serum. J. biol. Chem., 164, 321-329.

Blahd, W. H., Cassen, B., and Lederer, M. (1964). Decreased body potassium in nondystrophic relatives of patients with muscular dystrophy. A biochemical trait. New Engl. J. Med., 270, 197-198.

Blahd, W. H., Lederer, M., and Cassen, B. (1967). The significance of decreased body potassium concentrations in patients with muscular dystrophy and nondystrophic relatives. New Engl. J. Med., 276, 1349-1352.

Emery, A. E. H. (1965) Muscle histology in carriers of Duchenne muscular dystrophy. J. med. Genet., 2, 1-7.
Emery, A. E. H. (1967). The use of serum creatine kinase $\mathbb{D}$ for detecting carriers of Duchenne muscular dystrophy, pp. 90-97. In Exploratory Concepts in Muscular Dystrophy, and Related Disorders. International Congress Series No. 147. Excerpta Medica Foundation: Amsterdam.

Emery, A. E. H. (1969). Genetic counselling in x-linked T muscular dystrophy. J. neurol. Sci., 8, 579-587.

Gardner-Medwin, D. (1968). Studies of the carrier state in $\frac{\rho}{工}$ the Duchenne type of muscular dystrophy. 2. Quantitative electromyography as a method of carrier detection. J. Neurol. Neurosurg. Psychiat., 31, 124-134.

Griffiths, P. D. (1966). Serum levels of ATP: creatine $\overrightarrow{\vec{D}}$ phosphotransferase (creatine kinase). The normal range $\stackrel{\oplus}{\rightarrow}$ and effect of muscular activity. Clin. chim. Acta., 13, 으 413-420.

Hudgson, P., Gardner-Medwin, D., Pennington, R. J. T., and Walton, J. N. (1967) Studies of the carrier state in $\vec{\Phi}$ the Duchenne type of muscular dystrophy. Part 1. Effect $\varrho$ of exercise on serum creatine kinase activity. J. Neurol. Neurosurg. Psychiat., 30, 416-419.

Johnston, H. A., Wilkinson, J. H., Withycombe, W. A., $\overrightarrow{0}$ and Raymond, S. (1966). Alpha-hydroxybutyrate dehydro- $\rightarrow$ genase activity in sex-linked muscular dystrophy. J. clin. $\vec{\omega}$ Path., 19, 250-256.

Lanari, A., Gonzalez Perez, M., and Semeniuk, G. B. (1970). Increased levels of serum-creatine-phosphokinase after $\overline{7}$ transient limb ischaemia in patients with muscular w dystrophy. Lancet, 1, 217-218.

Pearce, G. W., Pearce, J. M. S., and Walton, J. N. (1966) ir The Duchenne type muscular dystrophy: histopathologicosi if studies of the carrier state. Brain, 89, 109-120.

Pearce, J. M. S., Pennington, R. J., and Walton, J. N. (1964§ Serum enzyme studies in muscle disease. J. Neurब Neurosurg. Psychiat., 27, 1-4.

Roy, S., and Dubowitz, V. (1970). Carrier detection Duchenne muscular dystrophy. A comparative study of $\frac{\rho}{O}$ electron microscopy, light microscopy and serum enzyme্ J. neurol. Sci., 11, 65-79.

Stephens, J., and Lewin, E. (1965). Serum enzyme variatiom $\overrightarrow{0}$ and histological abnormalities in the carrier state Duchenne dystrophy. J. Neurol. Neurosurg. Psychiat.,. 28, 104-108.

Thomson, W. H. S. (1968). Determination and statistical analyses of the normal ranges for five serum enzymes. Clin. chim. Acta., 21, 469-478.

Vejjajiva, A., and Teasdale, G. M. (1965). Serum creatine ฏ kinase and physical exercise. Brit. med. J., 1, 1653-1654.

Walton, J. N., and Gardner-Medwin, D. (1969). In Disorders $\varrho$ of Voluntary Muscle. Pp. 467-468. Edited by J. N. $\overrightarrow{\bar{O}}$ Walton. Churchill: London.

Wiesmann, U., Moser, H., Richerich, R., and Rossi, E. (1965). Progressive Muskeldystrophie. VII. Die Erfassung von Heterozygoten der Duchenne-Muskeldystrophie durch Messung der Serum-Kreatin-Kinase unter lokalisierter Arbeitsbelastung in Anoxie. Klin. Wschr., 43, 1015-1022. 